\title{
ANALISIS KUALITAS PELAYANAN PROFESIONAL PEMBERI ASUHAN (PPA) DENGAN KEPUASAN PADA PASIEN RAWAT JALAN DI POLI PENYAKIT DALAM
}

\author{
Rahmania Ambarika, Langit Kresna Janitra \\ IIK STRADA Indonesia \\ Korespodensi penulis: rahmania.ambar@gmail.com
}

\begin{abstract}
Abstrak
Latar belakang: Untuk menciptakan kepuasan pasien, Rumah Sakit harus menciptakan dan mengelola suatu sistem untuk memperoleh pasien yang lebih banyak dan kemampuan untuk mempertahankan pasiennya. Proses pelayanan dan asuhan pasien bersifat dinamis dan melibatkan banyak Profesional Pemberi Asuhan (PPA) dan melibatkan berbagai unit pelayanan. Banyaknya permasalahan tentang kurangnya kepuasan dari pelayanan petugas kesehatan, salah satunya dikarenakan kurangnya kualitas pelayanan pemberian asuhan.

Tujuan: Penelitian ini bertujuan untuk menganalisis hubungan kualitas pelayanan petugas kesehatan dengan kepuasan pada pasien rawat jalan di Rumah Sakit Kartini Mojokerto.

Metode: Penelitian ini menggunakan desain kuantitatif analitik dengan pendekatan cross sectional. Populasinya semua pasien rawat jalan yang sudah mendapatkan pelayanan di Poli penyakit dalam Rumah Sakit Kartini Mojokerto dengan jumlah 156 responden. Sampel menggunakan Simple Random Sampling berjumlah 112 responden. Variable Independentnya adalah kualitas pelayanan. Variable Dependentnya adalah kepuasan pasien rawat jalan. Analisa data menggunakan chi square.

Hasil: Berdasarkan hasil analisis tersebut menunjukkan bahwa ada hubungan kualitas pelayanan dengan kepuasan pasien dengan nilai $p$-value $0,008<0,05$ maka $\mathrm{H}_{0}$ ditolak dan $\mathrm{H}_{1}$ diterima.

Simpulan: ada hubungan yang signifikan antara kualitas pelayanan petugas kesehatan dengan kepuasan pada pasien rawat jalan di Rumah Sakit Kartini Kabupaten Mojokerto.
\end{abstract}

Kata kunci: Kepuasan pasien, Kualitas pelayanan

\section{Pendahuluan}

Proses pelayanan dan asuhan pasien bersifat dinamis dan melibatkan banyak Profesional Pemberi Asuhan (PPA) dan melibatkan berbagai unit pelayanan. Integrase dan koordinasi kegiatan pelayanan dan asuhan pasien merupakan sasaran yang menghasilkan efisiensi, penggunaan dan sumber lainnya efektif dan hasil asuhan pasien yang lebih baik.

Penilaian pasien terhadap pelayanan perawat bersumber dari pengalaman pasien. Aspek pengalaman pasien dapat diartikan sebagai suatu perlakuan atau tindakan dari perawat yang sedang atau pernah dijalani, dirasakan dan ditanggung oleh seseorang yang menggunakan pelayanan perawat (Jatmiko, 2013).

Faktor pendidikan mempengaruhi perilaku kerja, makin tinggi pendidikan akan berbanding lurus dengan perilaku kerja seseorang (Pangewa, 2007). Perilaku kerja merupakan tanggapan atau reaksi seseorang yang timbul berupa perbuatan atau sikap maupun anggapan seseorang terhadap pekerjaannya (Maulana, 2013). Perilaku dalam memberikan pelayanan sejalan dengan tingkat pendidikan Profesional Pemberi Asuhan (PPA) merupakan pendidikan tinggi meliputi Dokter, Perawat, Bidan, Apoteker, Analis dan Ahli Gizi yang dapat menimbulkan perubahan yang berarti terhadap cara PPA memberikan asuhan 
secara bertahap dan beralih dari yang semula berorientasi pada tugas menjadi berorientasi pada tujuan yang berfokus pada pemberian asuhan pasien secara efektif dengan pendekatan holistik dan proses komunikasi terhadap pasien.

Banyaknya permasalahan tentang kurangnya kepuasan dari pelayanan petugas kesehatan, salah satunya dikarenakan kualitas petugas kesehatan yang belum sesuai dengan standart operasional yang sudah ada. Berdasarkan data dari Dinas Kesehatan Kabupaten Mojokerto selama tiga tahun terakhir, Rumah Sakit Kartini yang setiap tahunnya mengalami penurunan kunjungan pasien rawat jalan pada tahun 2015 sampai dengan 2017, pada tahun 2015 jumlah kunjungan pasien sebanyak 26.801 orang, tahun 2016 sebanyak 23.173 orang, tahun 2017 sebanyak 20.756 orang (Dinkes Mojokerto, 2017). Terjadinya penurunan jumlah kunjungan pasien setiap tahun dikarenakan ada dua faktor yaitu kepuasan dan pelayanan yang memungkinkan jumlah kunjungan pasien yang sakit diwilayah kerja Rumah Sakit Kartini berkurang, pelayanan dari Rumah Sakit Kartini apakah selama ini diberikan kepada pasien menimbulkan ketidakpuasan dan berpengaruh terhadap kualitas pelayanan yang diberikan dan penurunan jumlah pasien (Rekam Medik Rumah Sakit Kartini, 2017).

Rumah Sakit adalah suatu kesatuan organisasi kesehatan fungsional yang merupakan pusat pengembangan kesehatan masyarakat yang juga membina peran serta masyarakat di samping memberikan pelayanan secara menyeluruh dan terpadu kepada masyarakat di wilayah kerjanya dalam bentuk kegiatan pokok. Dengan kata lain Rumah Sakit mempunyai wewenang dan tanggung jawab atas pemeliharaan kesehatan masyarakat dalam wilayah kerjanya, (satrianegara 2014).

Pelayanan kesehatan merupakan faktor penting dalam meningkatkan derajat kesehatan dan kesejahteraan setiap insan diseluruh dunia. Menurut Undang - Undang No. 36 pasal 19 tahun 2009 tentang kesehatan, menjelaskan bahwa setiap orang mempunyai hak dalam memperoleh pelayanan kesehatan dan pemerintah bertanggung jawab atas ketersediaan segala bentuk upaya kesehatan yang bermutu, aman, efisien, dan terjangkau oleh seluruh lapisan masyarakat. Salah satu upaya tersebut yaitu dengan peningkatan ketersediaan dan pemerataan fasilitas kesehatan dasar seperti Rumah Sakit di setiap daerah (Bappenas, 2013).

Kualitas pelayanan (service quality) dapat diketahui dengan cara membandingkan persepsi para konsumen atas pelayanan yang mereka terima dengan pelayanan yang sesungguhnya mereka harapkan terhadap atribut-atribut pelayanan suatu perusahaan. Kualitas pelayanan dipersepsikan baik dan memuaskan jika jasa yang diterima atau dirasakan (perceived service) sesuai dengan yang diharapkan, jika jasa yang diterima melampaui harapan konsumen, maka kualitas pelayanan dipersepsikan sangat baik dan berkualitas. Kualitas pelayanan dipersepsikan buruk jika jasa yang diterima lebih rendah daripada yang diharapkan (Amrizal, 2014). Kualitas pelayanan kesehatan adalah menunjuk pada tingkat kesempurnaan penampilan pelayanan kesehatan yang dapat memuaskan setiap pemakai jasa pelayanan kesehatan sesuai dengan tingkat kepuasan rata-rata penduduk, tata cara penyelenggaraannya sesuai dengan standar dan kode etik profesi yang telah ditetapkan.

Kualitas pelayanan (service quality) dapat diketahui dengan cara membandingkan persepsi para konsumen atas pelayanan yang mereka terima dengan pelayanan yang sesungguhnya mereka harapkan terhadap atribut-atribut pelayanan suatu perusahaan. Kualitas pelayanan dipersepsikan baik dan memuaskan jika jasa yang diterima atau dirasakan (perceived service) sesuai dengan yang diharapkan, jika jasa yang diterima melampaui harapan konsumen, maka kualitas pelayanan dipersepsikan sangat baik dan berkualitas (Wijoyo, 2012).

Memahami kebutuhan dan keinginan pasien adalah hal penting yang mempengaruhi kepuasan pasien. Pasien yang puas merupakan aset yang sangat berharga 
karena apabila pasien merasa puas mereka akan terus melakukan pemakaian terhadap jasa pilihannya, tetapi jika pasien merasa tidak puas mereka akan memberitahukan dua kali lebih hebat kepada orang lain tentang pengalaman buruknya. Untuk menciptakan kepuasan pasien, rumah sakit harus menciptakan dan mengelola suatu sistem untuk memperoleh pasien yang lebih banyak dan kemampuan untuk mempertahankan pasiennya dengan cara mningkatkan kualitas pelayanan.

Secara umum penelitian ini dilakukan untuk menganalisis hubungan kualitas pelayanan petugas kesehatan dengan kepuasan pada pasien rawat jalan di Poli
Penyakit dalam Rumah Sakit Kartini Mojokerto.

\section{Metode Penelitian}

Penelitian ini menggunakan desain kuantitatif analitik dengan pendekatan cross sectional. Populasinya semua pasien rawat jalan yang sudah mendapatkan pelayanan di Poli penyakit dalam Rumah Sakit Kartini Mojokerto dengan jumlah 156 responden. Sampel menggunakan Simple Random Sampling berjumlah 112 responden. Variable Independentnya adalah kualitas pelayanan. Variable Dependentnya adalah kepuasan pasien rawat jalan. Analisa data menggunakan analisis Chi square.

\section{Hasil dan Pembahasan}

Tabel 1. Karakteristik Responden dan Variabel

\begin{tabular}{lcc}
\hline Jenis Kelamin & Frekuensi & Prosentase (\%) \\
\hline Laki-laki & 33 & 29 \\
\hline Perempuan & 79 & 71 \\
\hline Lama menderita sakit & 30 & 27 \\
\hline$<6$ bulan & 82 & 73 \\
\hline$>6$ bulan & & \\
\hline Penyakit & 44 & 39 \\
\hline Hipertensi & 27 & 24 \\
\hline Diabetes & 19 & 17 \\
\hline Stroke & 22 & 20 \\
\hline Penyakit lainnya & & \\
\hline Pendidikan & 34 & 30 \\
\hline SMP & 75 & 67 \\
\hline SMA & 3 & 3 \\
\hline Perguruan Tinggi & & \\
\hline Kualitas pelayanan & 89 & 79,5 \\
\hline Baik & 21 & 18,8 \\
\hline Cukup & 2 & 1,7 \\
\hline Kurang & & 94,6 \\
\hline Kepuasan & 66 & 5,4 \\
\hline Puas & 6 & \\
\hline Tidak puas & & \\
\hline
\end{tabular}

Tabel 2. Hasil analisis chi square

\begin{tabular}{lcrr}
\hline & Chi-Square Tests & \\
\hline & Value & df & \multicolumn{2}{c}{$\begin{array}{c}\text { Asymptotic } \\
\text { Significance (2-sided) }\end{array}$} \\
\hline Pearson Chi-Square & $27.286^{\text {a }}$ & 2 & .000 \\
\hline Likelihood Ratio & 32.158 & 2 & .000 \\
\hline $\begin{array}{l}\text { Linear-by-Linear } \\
\text { Association }\end{array}$ & 22.868 & 1 & .000 \\
\hline N of Valid Cases & & & \\
\hline
\end{tabular}

1 cells $(16.7 \%)$ have expected count less than 5 . The minimum expected count is 4.50 . 
Hasil penelitian didapatkan bahwa $\mathrm{p}=0,000$ dengan $\mathrm{p}$ value $<0,05$, sehingga $\mathrm{H} 1$ diterima dan $\mathrm{H} 0$ ditolak yang berarti bahwa terdapat hubungan kualitas pelayanan petugas kesehatan dengan kepuasan pada pasien rawat jalan di Rumah Sakit Kartini Kabupaten Mojokerto.

\section{Kualitas Pelayanan Profesional Pemberi Asuhan (PPA) Pada Pasien Rawat Jalan Di Poli Penyakit Dalam}

Berdasarkan hasil penelitian diketahui bahwa sebagian besar responden berpendapat bahwa kualitas pelayanan dalam kategori baik sebanyak 89 responden (79,5\%).

Kualitas adalah sesuatu yang diputuskan oleh pelanggan. Kualitas didasarkan pada pengalaman aktual pelanggan atau konsumen terhadap produk atau jasa yang diukur berdasarkan persyaratan-persyaratan tersebut (Mongkaren, 2013). Kualitas pelayanan dapat diartikan sebagai upaya pemenuhan kebutuhan dan keinginan konsumen serta ketepatan penyampaiannya dalam mengimbangi harapan konsumen (Amrizal, 2014)

Kualitas pelayanan (service quality) dapat diketahui dengan cara membandingkan persepsi para konsumen atas pelayanan yang mereka terima dengan pelayanan yang sesungguhnya mereka harapkan terhadap atribut-atribut pelayanan suatu perusahaan. Kualitas pelayanan dipersepsikan baik dan memuaskan jika jasa yang diterima atau dirasakan (perceived service) sesuai dengan yang diharapkan, jika jasa yang diterima melampaui harapan konsumen, maka kualitas pelayanan dipersepsikan sangat baik dan berkualitas. Kualitas pelayanan dipersepsikan buruk jika jasa yang diterima lebih rendah daripada yang diharapkan (Amrizal, 2014). Kualitas pelayanan kesehatan adalah menunjuk pada tingkat kesempurnaan penampilan pelayanan kesehatan yang dapat memuaskan setiap pemakai jasa pelayanan kesehatan sesuai dengan tingkat kepuasan rata-rata penduduk, tata cara penyelenggaraannya sesuai dengan standar dan kode etik profesi yang telah ditetapkan.
Masyarakat sebagai konsumen tentu menginginkan pelayanan yang berkualitas. Kualitas pelayanan didefinisikan sebagai tingkat keunggulan yang diharapkan dan pengendalian atas tingkat keunggulan tersebut untuk memenuhi keinginan pelanggan (Tjiptono, 2008, dalam Dimas dan Oktafani, 2014). Kualitas pelayanan dapat diartikan sebagai upaya pemenuhan kebutuhan dan keinginan konsumen serta ketepatan penyampaiannya dalam mengimbangi harapan konsumen (Dimas dan Oktafani, 2014).

Salah satu pelayanan yang banyak dimanfaatkan oleh masyarakat adalah pelayanan kesehatan. Menurut Azwar (2014) pemanfaatan pelayanan kesehatan adalah penggunaan fasilitas pelayanan yang disediakan baik dalam bentuk rawat jalan, rawat inap, kunjungan rumah oleh petugas kesehatan ataupun bentuk kegiatan lain dari pemanfaatan pelayanan tersebut yang didasarkan pada ketersediaan dan kesinambungan pelayanan, penerimaan masyarakat dan kewajaran, mudah dicapai oleh masyarakat, terjangkau serta bermutu.

Berdasarkan beberapa pendapat tersebut di atas dapat disimpulkan bahwa bahwa kualitas pelayanan merupakan suatu kunci penting yang menjadi salah satu faktor dari kepuasan pasien di Poli Penyakit Dalam Rumah Sakit.

\section{Kepuasan Pasien Rawat Jalan Di Poli Penyakit Dalam}

Berdasarkan hasil penelitian diketahui hampir seluruh responden berpendapat bahwa kepuasan dalam pelayanan dalam kategori puas sebanyak 106 responden $(94,6 \%)$.

Memahami kebutuhan dan keinginan pasien adalah hal penting yang mempengaruhi kepuasan pasien. Pasien yang puas merupakan aset yang sangat berharga karena apabila pasien merasa puas mereka akan terus melakukan pemakaian terhadap jasa pilihannya, tetapi jika pasien merasa tidak puas mereka akan memberitahukan dua kali lebih hebat kepada orang lain tentang pengalaman buruknya. Untuk menciptakan 
kepuasan pasien, rumah sakit harus menciptakan dan mengelola suatu sistem untuk memperoleh pasien yang lebih banyak dan kemampuan untuk mempertahankan pasiennya.

Pasien adalah orang sakit yang dirawat dokter dan tenaga kesehatan lainnya ditempat praktek (Yuwono, 2013). Sedangkan kepuasan adalah perasaan senang seseorang yang berasal dari perbandingan antara kesenangan terhadap aktivitas dan suatu produk dengan harapannya (Nursalam, 2011). Kotler (dalam Nursalam, 2011) menyebutkan bahwa kepuasan adalah perasan senang atau kecewa seseorang yang muncul setelah membandingkan antara persepsi atau kesannya terhadap kinerja atau hasil suatu produk dan harapan-harapannya. Westbrook \& Reilly (dalam Tjiptono, 2014) berpendapat bahwa kepuasan pelanggan merupakan respon emosional terhadap pengalamanpengalaman berkaitan dengan produk atau jasa tertentu yang dibeli, gerai ritel, atau bahkan pola perilaku (seperti perilaku berbelanja dan perilaku pembeli), serta pasar secara keseluruhan. Menurut Yamit (2012), kepuasan pelanggan adalah hasil (outcome) yang dirasakan atas penggunaan produk dan jasa, sama atau melebihi harapan yang diinginkan. Sedangkan Pohan (2014) menyebutkan bahwa kepuasan pasien adalah tingkat perasaan pasien yang timbul sebagai akibat dari kinerja layanan kesehatan yang diperolehnya, setelah pasien membandingkan dengan apa yang diharapkannya. Pendapat lain dari Endang (dalam Mamik, 2010) bahwa kepuasan pasien merupakan evaluasi atau penilaian setelah memakai suatu pelayanan, bahwa pelayanan yang dipilh setidak-tidaknya memenuhi atau melebihi harapan.

Berdasarkan hasil peneliitian maka dapat disimpulkan bahwa kepuasan pasien adalah hasil penilaian dalam bentuk respon emosional (perasaan senang dan puas) pada pasien karena terpenuhinya harapan atau keinginan dalam menggunakan dan menerima pelayanan perawat.

\section{Hubungan Kualitas Pelayanan Profesional Pemberi Asuhan (PPA) Dengan Kepuasan Pada Pasien Rawat Jalan Di Poli Penyakit Dalam}

Hasil analisis antara variabel kualitas dengan kepuasan pelayanan diperoleh nilai $p$ value $0,008<0,05$ maka $\mathrm{H}_{0}$ ditolak dan $\mathrm{H}_{1}$ diterima, artinya ada hubungan antara kualitas pelayanan petugas kesehatan dengan kepuasan pada pasien rawat jalan di poli penyakit dalam Rumah Sakit Kartini Kabupaten Mojokerto.

Kualitas pelayanan (service quality) dapat diketahui dengan cara membandingkan persepsi para konsumen atas pelayanan yang mereka terima dengan pelayanan yang sesungguhnya mereka harapkan terhadap atribut-atribut pelayanan suatu perusahaan. Kualitas pelayanan dipersepsikan baik dan memuaskan jika jasa yang diterima atau dirasakan (perceived service) sesuai dengan yang diharapkan, jika jasa yang diterima melampaui harapan konsumen, maka kualitas pelayanan dipersepsikan sangat baik dan berkualitas. Kualitas pelayanan dipersepsikan buruk jika jasa yang diterima lebih rendah daripada yang diharapkan (Amrizal, 2014). Kualitas pelayanan kesehatan yang baik ditunjukkan dengan kesempurnaan penampilan pelayanan kesehatan yang dapat memuaskan setiap pemakai jasa pelayanan kesehatan sesuai dengan tingkat kepuasan, tata cara penyelenggaraannya asuhan sesuai dengan standar dan kode etik profesi yang telah ditetapkan.

\section{Simpulan}

a. Sebagian besar responden berpendapat bahwa kualitas pelayanan dalam kategori baik sebanyak 89 responden $(79,5 \%)$.

b. Hampir seluruh responden berpendapat bahwa kepuasan dalam pelayanan dalam kategori puas sebanyak 106 responden $(94,6 \%)$.

c. Ada hubungan yang signifikan antara kualitas pelayanan petugas kesehatan dengan kepuasan pada pasien rawat jalan di poli penyakit dalam Rumah Sakit Kartini Kabupaten Mojokerto. 


\section{Referensi}

Arita Muwarn, (2012). Manajemen Kesehatan, Yogyakarta: Penerbit Gosyen.

Arini Indriyasari, (2017), Analisis Faktor Tunggu Pasien Keluar Rumah Sakit Di RSUD Dr. Iskak Tulungagung, (Tesis), Kediri: Stikes Surya Mitra Husada

Bustami, Ms (2011). Penjaminan Mutu Pelayanan, Jakarta: Penerbit Erlangga

Depkes RI, (2008). Keputusan Menteri Kesehatan Republik Indonesia No 129 Mengenai Standart Pelayanan Minimal

Menpan RI, (2017) Peraturan Menteri Pendayagunaan Aparatur Negara Dan Reformasi Birokrasi Repuplik Indonesia No. 14 Tentang Pedoman Penyusunan Survei Kepuasan Masyarakat Unit Penyelenggara Pelayanan Publik

Dhita, Anggita, (2012), Analisis Waktu tunggu Pemberian Informasi tagihan pasien pulang rawat inap RS Graha Permata Ibu.

Notoatmojo, Soekidjo, (2009). Pengembangan Sumber Daya Manusia, Jakarta: Penerbit: Rineka Cipta

Notoatmodjo, Soekidjo (2010) Metode penelitian kesehatan. Jakarta: Penerbit : PT Rineka Cipta

Notoatmojo, Soekidjo (2005) Metodologi Penelitian Kesehatan, Jakarta: Penerbit: Rineka Cipta

Nursalam, (2011), Konsep \& Penerapan Metodologi Penelitian Ilmu Keperawatan, Jakarta, Penerbit Salemba merdeka.

Hermanto, 2010. Pengaruh Persepsi Mutu Pelayanan Kebidanan terhadap Kepuasan Pasien Rawat Inap Kebidanan Di RSUD Dr. H.Soemarnososroatmodjo

Bulungan Kalimantan Timur (Tesis) : Semarang : Universitas Diponegoro
Rahmat Surya N, (2017) Kepuasan Pasien Rawat Inap Ditinjau dari Manajemen Sumber Daya Manusia Di RS Muhamadiyah Ahmad Dahlan Kota Kediri (tesis) : Kediri: Stikes Surya Mitra Husada

Susatyo, Herlambang (2012), Manajemen Rumah Sakit, Sleman Yogyakarta: Penerbit Gosyen.

Sugiyono, (2010) Statistik Untuk Penelitian, Jakarta: Penerbit: Rineka Cipta

Sugiyono, (2016). Metode Penelitian dan Pendidikan, cetakan ke 23 Bandung: Penerbit: Alfaeta.

Wilde Larson (2010) Pengukuran Tingkat Kepuasan Pelangan. Jakarta: Salemba

Arini Indirayasari (2017) Analisis Faktor Tunggu Pasien Keluar Rumah Sakit Di RSUD DR. ISKAK Tulungagung (Tesis) : Kediri: Stikes Surya Mitra Husada 